\title{
Diabetik polinöropatik hastalarda memantinin ağrı üzerine etkinliği
}

\author{
Effect of memantine on painful in the diabetic polyneuropathic patients \\ Şeyda Figül Gökçe*, Burhanettin Çiğdem, Aytekin Akyüz, Ertuğrul Bolayır, Suat \\ Topaktaş
}

Nöroloji Kliniği (Dr. Ş. F. Gökçe), Numune Hastanesi, TR-58100 Sivas, Nöroloji Anabilim Dalı (Yrd. Doç. B. Çiğdem, Prof. Dr. E. Bolayır, Prof. Dr. S. Topaktaş), Cumhuriyet Üniversitesi Tıp Fakültesi, TR-58140 Sivas, Nöroloji Kliniği (Prof. Dr. A. Akyüz), Özel Kent Hastanesi, TR-35630 İzmir

\section{Özet}

Diyabetik periferal nöropati (DPN) klinik pratikte en sık karşılaşılan kronik nöropatik ağrı semptomlarından birisidir. Diyabetik nöropatili hastalarda çeşitli tedavi yöntemleri denenmektedir. Son yıllarda primer afferent-spinotalamik nöron sinapslarında eksitatör transmisyonun modülasyonu için N-methyl-D-aspartate (NMDA) reseptör antagonistleri kullanılmaktadır. NMDA reseptör antagonistlerinin kronik ağrı durumlarında opioid analjezikler kadar etkin olduğu da gösterilmiştir. Bu çalışmada diabetik polinöropatili hastalarda prospektif olarak NMDA reseptör antagonisti Memantin'in farklı iki dozda, ağrı üzerine olan etkinliğini değerlendirmeyi amaçladık. Tip 2 diyabetli ve diabetik nöropatisi olan 24 hasta çalışmaya dahil edildi. Diyabetik nöropati tanısı klinik (anamnez, motor, duyusal ve refleks muayenesi) ve elektrofizyolojik testler ile konuldu. Hastaların ağrı şikayetleri tedavi öncesi ve sonrası Vizüel Ağrı Skalası (VAS) ile değerlendirildi. Hastalara birinci hafta $10 \mathrm{mg}$, daha sonra altı hafta boyunca $20 \mathrm{mg}$ memantin verildi. Yedinci hafta sonunda hastalar tekrar değerlendirildi. Tedaviye ara vermeksizin bir hafta $30 \mathrm{mg}$, daha sonra alt1 hafta boyunca $40 \mathrm{mg}$ memantin uyguland. Her iki tedavi grubunda kontrol grubuna kıyasla VAS değerlerinde anlamlı düzelme gözlenirken, tedavi grupları arasındaki farkda önemli bulundu. Sonuç olarak diyabetik polinöropatide Memantin tedavisi nöropatik ağrının tedavisinde düzelme sağlamaktadır.

Anahtar sözcükler: Diyabetik nöropati, NMDA reseptörleri, ağrı, VAS, memantin

\begin{abstract}
Diabetic peripheral neuropathy (DPN) is one of the most frequent chronic pain symptoms. Several therapeutic modalities have been used for the patients with DPN. In recent years, NMDA receptor antagonists for modulation of excitatory transmission at primary afferent spino-thalamic neuron synapses are being used. It has been shown that NMDA receptor antagonists are as effective as opioid analgesics in cases with chronic pain. The aim of this study was to investigate on the pain effectiveness of NMDA receptor antagonist Memantin at two different doses prospectively. Twenty four type 2 diabetic neuropathy patients were included into the study. The diagnosis of diabetic neuropathy was based on clinical signs and symptoms (history, clinical examination of muscle strength, sensorial and deep tendon reflexes), and electrophysiological tests. Pain complaints of the patients were evaluated by using visual pain scala before and after the treatment. Patients were administered $10 \mathrm{mg}$ Memantin for the first week followed by then $20 \mathrm{mg}$ for consecutive 6 week. Without interruption of treatment $30 \mathrm{mg}$ Memantin for one week and then 40 mg Memantin for 6 week were administered. There was a significant improvement in both treatment groups as compared to control group. Between the treatment groups was significant. It was concluted that; Memantin was effective in reducing neuropathic pain in patients with DPN.
\end{abstract}

Keywords: Diabetic neuropathy, NMDA receptors, pain, VAS, memantin

Geliş tarihi/Received: 20 Eylül 2014; Kabul tarihi/Accepted: 01 Aralık 2014

*İletişim adresi:

Dr. Şeyda Figül Gökçe, Nöroloji Kliniği, Sivas Numune Hastanesi, TR-58030 Sivas. E-posta: seydafigul_gokce@hotmail.com 


\section{Giriş}

Nöropati, diyabetes mellituslu hastalarda en sık görülen komplikasyondur. Genellikle hastalığın süresi ve hipergliseminin ciddiyeti ile ilişkilidir. Diyabetik periferik nöropati (DPN) klinik pratikte en sık karşılaşılan kronik nöropatik ağrı nedenlerinden birisidir [1, 2]. Diyabetik nöropati klasifiye edildiğinde yaygın ve fokal olarak iki sinıfa ayrılmaktadır. Distal simetrik sensori-motor polinöropati kliniği en sık karşılaşılan tablodur ve sıklıkla alt ekstremitelerde yüzeyel yanma, ağrı, allodinia, hiperaljezi, disestezis gibi semptomlarla karşımıza çıkmaktadır [3, 4].

Son 10-15 yıldır DPN nin etiyopatolojik mekanizmalarını açıklamak için oldukça kapsamlı çalışmalar yapılmış ve multifaktoriyel etkenler üzerinde durulmuştur. Uzun dönem klinik çalışmaları içeren ve glisemik kontrolün öneminin belirtildiği Diyabet Kontrol ve Komplikasyonları Önleme Grubunun araştırmalarında Tip 1 diyabetes mellitus'lu hastalarda sıkı glisemik kontrol ile nöropatinin progresyonun yavaşladığı ve ortaya çıkışının geciktiği gösterilmiştir [5].

DPN'li hastaların ayak ve ellerinde duyu kaybı yada duyu azalması, alt ekstremite kaslarında zayıflık ve ağrının yanında küçük liflerin tutulumuna bağlı olarak ayaklarda kramplar, hiperaljezi ve spontan yanmalar da görülebilir $[4,6]$.

Diyabetik polinöropatili hastalardaki ağrıya yönelik oldukça fazla sayıda tedavi yöntemi bulunmasına rağmen henüz net ve tam bir tedavi şekli yoktur. Bu da sinir hasarını düzeltecek ya da rejenere edecek bir tedavinin olmamasından kaynaklanmaktadır [7].

Son yıllarda primer afferent-spinotalamik nöron sinapslarının eksitatory transmisyonlarının modülasyonunda glutamat reseptörü hedef alınarak glutamat reseptörü subtipi olan N-methyl-D-aspartate (NMDA) reseptör antagonistleri diyabetik nöropatinin tedavisinde kullanılmaktadırlar [8]. Aynı yaklaşımla bazı çalışmalarda NMDA reseptör antagonistlerinin kronik ağrı durumlarında da opioid analjezikler kadar etkin olduğu da gösterilmiştir [9].

Sonuç olarak bu çalışmada periferik diyabetik polinöropatili hastalarda NMDA reseptör antagonisti Memantinin farklı iki dozda, nöropatik ağrı üzerine olan etkinliğini değerlendirmeyi amaçladık.

\section{Gereç ve yöntem}

Bu çalışma (2004-6/3 karar no'lu yerel etik kurul onayı alındıktan sonra) Cumhuriyet Üniversitesi Tıp Fakültesi Hastanesi Dahiliye ve Endokrinoloji servislerinde diyabet tanısı konularak regülasyonu sağlanmış ve Nöroloji polikliniğinde de ağrılı diyabetik polinöropati tanısıyla takip edilen 28 Tip II diyabetik hastaya oral yoldan 20 ve 40 miligramlık dozlarda Memantin verilerek ağrı semptomlarının azaltılması amaçlanan bu prospektif çalışma 24 hasta ile tamamlanmıştır. Hastalara Tip II DM tanısı ADA (American Diabetes Association) kriterlerine göre konuldu. Diyabetik nöropati tanıs1 klinik ve elektrofizyolojik testler ile konulurken, hastaların çalışmaya alınmadan en az 4 ay önceden nöropati açısından herhangi bir ilaç tedavisi almamış olma özellikleri arandı.

DM ile birlikte periferal nöropati yaratabilecek hastalıkları bulunanlar (dejeneratif nörolojik hastalık, tiroid fonksiyon bozukluğu, amputasyon, aktif enfeksiyon, Charcot eklemi, öyküsü olan hastalar, madde bağımlılığı bulunanlar, anormal hepatik ve renal fonksiyonlu hastalar, periferal vasküler patolojili hastalar) ile dekompanse kalp yetmezliği öyküsü olan hastalar çalışmaya alınmadı. Çalışmaya alınan hastaların çalışma öncesinde $\mathrm{CBC}$, Akş, HbA1c ve biyokimyasal değerleri incelendi.

Hastalar nöropati semptomlarının varlığı ve süresi açısından sorgulandı ve hastaların tümünün nörolojik muayenesi yapıldı. Motor kayıp, duysal semptom ve refleks kaybı tespit edilip EMG sonuçlarıyla diyabetik polinöropati tanısı desteklendi. Hastaların 12 'sinde dört ekstremitede, onaltısında ise yalnızca alt ekstremitede ağrı mevcuttu. Şikayetlere geceleri olan ve uzun süre ayakta kalmakla şiddetlenen yanma hissi eşlik 
ediyordu. Hastaların tamamı diyabet regülasyonu açısından takip altındaydı. Tedavi öncesi görüşmede Vizüel Ağrı Skalası ile hastaların mevcut ağrı şikayeti için 0 ile 10 arasında değerler belirlendi. Bu 28 hastanın her birine birinci hafta $10 \mathrm{mg}$ ikinci hafta 20 mg verilecek şekilde Memantin başlandı. Yirmi mg Memantin hastalara altı hafta uygulandı. Yedinci hafta sonunda hastalar değerlendirilmek üzere çağırıldılar. Tedavi sonrası ağrı şikayetlerinin derecesi ile başlangıçta verdikleri değer hatıllatılarak aynı yöntemle kaydedildi. Yan etkiler açısından hastalar sorgulandılar. Tedaviye ara vermeksizin bir hafta $30 \mathrm{mg}$, sonrasinda toplam altı hafta uygulanacak şekilde $40 \mathrm{mg}$ Memantin başlandı. İkinci aşamadaki tedavi sırasında iki hasta tedavi protokolüne uyum göstermemeleri nedeniyle, iki hastada yan etkiler nedeniyle (sersemlik hissi) çalışmayı tamamlayamadılar. On dördüncü haftanın sonunda çalışmayı devam ettiren tüm hastaların tekrar VAS değerlendirilmesi yapıldı.

Hastaların 10'unda $20 \mathrm{mg}$ tedavi sirasinda hafif sersemlik hissi ve 6'sinda tedaviye uyumu etkilemeyecek şiddette bulantı yakınmaları oldu, ancak birinci hafta ve ikinci hafta içerisinde şikayetleri yok denecek kadar azalarak sonland. Bu aşamada tedavi 28 hasta ile bitirilirken, ikinci aşamada ise şiddetli sersemlik hissi nedeniyle 2 ve uyumsuzluk nedeniyle de 2 hasta olmak üzere 4 hastanın çalışma dışı kalması ile 24 hasta ile çalışma bitirildi.

Çalışmamızın verileri SPSS (versiyon 14,0) programına yüklendi. Verilerin değerlendirilmesinde: Tekrarlı ölçümlerde varyans analizi, Bonferroni testi ve Fisher Khi Kare testi uyguland. Elde edilen veriler tablolarda ortalama \pm standart sapma şeklinde verildi. Yanılma düzeyi 0,05 olarak alındı.

\section{Bulgular}

Çalışmaya aldığımız diyabetik polinöropatili hastaların 15 'i $(\% 62,5)$ kadın, geriye kalan 9'u $(\% 37,5)$ erkekti. Hastaların yaş ortalamaları 52,04 $\pm 11,83$ yıldı. Diyabetes mellituslu hastaların ortalama hastalık süreleri 9,54 $\pm 3,97$ yıl olarak bulundu. Hastalık süreleri 4 yıl ile 20 yıl arasında değişmekteydi. Hastaların hemoglobin değerleri 14,17 $\pm 1,08$; HbA1c değerleri ise 11,92 $\pm 2,21$; açlık kan şekeri düzeyleri 242,75 $\pm 55,64$ olarak belirlendi.

Çalışmaya aldığımız diyabetik polinöropatili hastaların Memantin ile tedavi öncesi ve altı haftalık $20 \mathrm{mg}$ tedavi ile altı haftalık $40 \mathrm{mg}$ 'lık Memantin ile tedavi sonrasında yaptığımız Vizüel Analog Skala değerleri karşılaştırıldığında her üç grup kendi arasında değerlendirildiğinde ölçüm değerleri anlamlı olarak farklı bulundu $(\mathrm{p}<0,05)$ (Tablo 1). VAS değerleri ikişerli gruplar olarak karşılaştırıldığında başlangıç ile 20 mg'lık tedavi arasında ve başlangıç ile 40 mg'lık tedavi arasındaki gruplar arasında önemli bir fark bulunurken $(\mathrm{p}<0,05), 20 \mathrm{mg}$ ile $40 \mathrm{mg}$ 'lı Memantin tedavi grupları arasında da önemli farkl11ık bulunmuştur $(\mathrm{p}<0,05)$.

Tablo 1. Gruplar arası VAS değerlerinin ortalaması.

\begin{tabular}{lllll}
\hline & Tedavi öncesi & $\begin{array}{l}\text { 20 mg Memantin } \\
\text { tedavi sonrası }\end{array}$ & $\begin{array}{l}\text { 40 mg Memantin } \\
\text { tedavi sonrası }\end{array}$ & p değeri \\
\hline VAS & $6,72 \pm 1,13$ & $6,02 \pm 1,10$ & $3,56 \pm 1,40$ & $\mathrm{X}_{2}=42,66 ; \mathrm{P}<0,05$ \\
\hline
\end{tabular}

\section{Tartışma}

Nöropatik ağrı tüm özellikleri ile yaşam kalitesini bozan ve bunun sonucunda ise hasta bireylerin çalışma kapasitelerini azaltan ve aynı zamanda sağlık kurumlarına olan ihtiyacı artıran bir klinik tablodur. Bu nedenle diyabetik polinöropatik ağrının da aralarında bulunduğu kronik nöropatik ağrı nedenlerine yönelik uygun tedavi için günümüzde birçok tedavi stratejisi geliştirilmektedir [10]. Periferal sinir hasarlarında spinal kordun dorsal boynuzundaki eksitatör amino asitlerin salınımı sonucu NMDA reseptörlerinde eksitasyon oluşmaktadır. NMDA reseptörlerinde devam eden bu stimülasyonun nöropatik ağrı mekanizmasında kritik bir öneme sahip olduğu da son yıllarda gösterilmiştir [11]. 
Diyabetik nöropatik ağrıda bilinen analjeziklere cevaplar sıklıkla zayıf olduğundan son yıllarda nöronal ağrı mekanizması ile ilişkilendirilen hipereksitabiliteyi azaltıcı tedavi modaliteleri üzerinde durulmaktadır. Bu tedavi stratejileri ise sinir hücresi içerisinde $\mathrm{Ca}$ penetrasyonu değişikliği sağlayarak hipereksitabilite üzerine etkili antikonvülzanlar ve glutamat reseptörleri üzerinden hipereksitabiliteyi azaltıcı özelliği bulunan NMDA reseptör antagonisti olan ilaçlardır [12]. NMDA reseptör antagonisti olarak gittikçe artan oranda kullanım yeri bulan Memantin NMDA reseptörlerinde mağnezyum blok alanları seviyesinde antagonistik aktivasyon sağlayarak hücre içerisine $\mathrm{Ca}$ ve $\mathrm{Na}$ geçişini engellemekte ve hipereksitabiliteyi önleyerek nöropatik ağrı üzerine etkinlik göstermektedir. NMDA reseptör antagonistlerinin kronik ağrı durumlarında klinik olarak kullanılabilirliği ve etkinliğini değerlendirmek amacı ile yapılmış sınırlı sayıda insan çalışması mevcuttur. Çünkü bu sınıf ilaçların doz bağımlı olarak ortaya çıkan yan etkileri mevcuttur. Fakat son yıllarda Memantin gibi voltaj bağımlı, orta derecede afiniteye sahip, kompetetif olmayan NMDA reseptör antagonistlerinin yanında, glisinB ve selektif NR2B antagonistlerinin de NMDA reseptör antagonistik etkileri belirlenerek minimal yan etki profilleri gösterilmiştir $[13,14]$. Ketamin ve dextromethorpham gibi spinal kordun dorsal boynuzunda bulunan NMDA reseptör aktivasyonuna antagonistik etki gösteren bu iki ilaç ile ilk olarak çalışmalar yapılmış ve günlük olarak ortalama $400 \mathrm{mg} / \mathrm{gün}$ dextromethorphamın ağrılı diyabetik nöropatinin tedavisinde etkili olduğu gösterilmiş beraberinde hem ketaminin hem de dextromethorphamın s1k yan etkilerinden dolayı bu ilaçların kullanımı sınırlandırılmıştır [13]. Farklı bir mekanizma ile NMDA antagonistik etkinliği bulunan Memantin ile son yıllarda Sang ve ark.'nın [15] yaptığı bir çalışmada (ağrı değerlendirilmesinin Gracely Box Scale ile yapıldığı) ancak yüksek dozlarda (960 mg/gün) dextromethorpham ile alınan ağrı cevaplarının Memantin ile eşdeğer olduğu gösterilmiş fakat bu dozlarda çoğu hastalarda ciddi yan etkiler görülerek ya düşük dozlara inilmiş ya da çalışma dışı bırakılmışlardır. Kirby ve ark.'nın [16] ağrılı periferal diyabetik nöropatililerde Memantinin etkinliğini belirlemek için yaptıkları çift kör, randomize, plasebo kontrollü bir çalışmada günlük 20 ve 40 mg'llk dozlarla yaptığ çalışmada VAS değerleri üzerinde $40 \mathrm{mg} \mathrm{m}^{\prime} \mathrm{l} \mathrm{k}$ dozun hem plasebo hemde $20 \mathrm{mg}$ 'lık doza göre anlamlı olarak daha etkili olduğunu belirtmişlerdir. Bu çalışmada yüksek doz grubunda yan etki ve bu nedenle tedaviyi bırakma oranlarının diğer tedavi grubundan farklı olmadığını da ortaya koymuşlardır. Yine Sang ve ark. [15] ise günlük $35 \mathrm{mg}$ lık memantinin ağrilı diabetik nöropatili hastalarda etkin bir doz olduğunu belirtmişler beraberinde bu dozlarda önemli oranlarda yan etki ile karşılaşmamışlardır. Çalışmamızda ise tedaviye başlamadan önce belirlenen VAS değerleri ile $20 \mathrm{mg}$ 'llk ve $40 \mathrm{mg}$ 'llk tedavi süreçleri sonunda belirlenen VAS değerleri arasında tedavi gruplarının lehine olacak şekilde bir farklılık mevcuttu. Tedavi gruplanı arasında VAS değerleri karşılaştırıldığında ise $40 \mathrm{mg}$ lehine olacak şekilde bir düzelme mevcuttu. Bizim çalışmamızın diğer çalışmalardan farkı ise 20 mg'lık tedavi sonunda da VAS değerlerinde anlamlı düzelme izlendi ayrıca $40 \mathrm{mg}$ gibi yüksek dozlara çıktığımızda tedavinin etkinliğinin doza bağımlı olarak arttığınıda belirledik.

Sonuç olarak; memantin, diyabetik polinöropatili hastalarda yaşam kalitesini bozan ağrı semptomlarının tedavisinde doza bağımlı olarak olumlu etkiler sağlamaktadır. Bu konuda daha büyük serilerde ayrıntılı çalışmalar yararlı olacaktır. 


\section{Kaynaklar}

1. Harati Y. Diabetic neuropathies: Unanswered questions. Neurol Clin 2007; 25: 303-17.

2. Charnogursky G, Lee H, Lopez N. Diabetic neuropathy. Handb Clin Neurol 2014; 120: 773-85.

3. Said G. Diabetic neuropathy. Handb Clin Neurol 2013; 115: 579-89.

4. Benbow SJ, MacFarlane IA. Painful diabetic neuropathy. Baillieres Best Pract Res Clin Endocrinol Metab 1999; 13: 295-308.

5. Martin CL, Albers JW. Pop-Busui R; DCCT/EDIC Research Group. Neuropathy and related findings in the diabetes control and complications trial/epidemiology of diabetes interventions and complications study. Diabetes Care 2014; 37: 31-8.

6. Thomas P, Tomlinson D. Diabetic and hypoglycemic neuropathy. In Dyck P, Thomas P, editors: Peripheral Neuropathy. 3rd ed. Philadelphia: W. B. Saunders Company 1993: 1219-50.

7. The Diabetes Control and Complications Trial Research Group. The effect of intensive diabetes therapy on the development and progression of neuropathy. Ann Intern Med 1995; 122: 561-8.

8. Lipton SA. Failures and successes of NMDA receptor antagonists: Molecular basis for the use of open-channel blockers like memantine in the treatment of acute and chronic neurologic insults. NeuroRx 2004; 1: 101-10.

9. Villetti G, Bergamaschi M, Bassani F. Antinociceptive activity of the N-methylD-aspartate receptor antagonist N-(2-Indanyl)-glycinamide hydrochloride (CHF3381) in experimental models of inflammatory and neuropathic pain. J Pharmacol Exp Ther 2003; 306: 804-14.

10. Gordon DB, Love G. Pharmacologic management of neuropathic pain. Pain Manag Nurs 2004; 5: 19-33.

11. Wang S, Lim G, Zeng Q, Sung B, Yang L, Mao J. Central glucocorticoid receptors modulate the expression and function of spinal NMDA receptors after peripheral nerve injury. J Neurosci 2005; 25: 488-95.

12. Jensen TS. Anticonvulsants in neuropathic pain: rationale and clinical evidence. Eur J Pain 2002; 6: 61-8.

13. Sang CN. NMDA-receptor antagonists in neuropathic pain: Experimental methods to clinical trials. J Pain Symptom Manage 2000; 19: 21-5.

14. Lipton SA, Choi Y-B, Takahashi T. Cysteine regulation of protein functionas exemplified by NMDA-receptor modulation. Trends Neurosci 2002; 25: 474-80.

15. Sang CN, Booher S, Gilron I, Parada S, Max MB. Dextromethorphan and memantine in painful diabetic neuropathy and postherpetic neuralgia: Efficacy and dose-response trials. Anesthesiology 2002; 96: 1053-61.

16. Kirby LC. Memantine in the treatment of diabetics with painful peripheral neuropathy: A placebo-controlled trial. 18th Annual Meeting of the American Academy of Pain Medicine, Feb 26-March 3, San Francisco, California 2002. 